\title{
Introduction
}

Developmentalist scholars like Elias, Goody and Mennell have theorised that, since the late Middle Ages, western Europe has undertaken a civilising process (Elias, 1939). For them, it is a process of continuous refinement that has involved diverse human habits. Goody (1982) and Mennell (1996) in particular, have focused their works on how the civilising process has changed the relationships between humans and food. All three scholars, however, have dealt with the issue of meat, analysing how, in western Europe and in France and Britain in particular, humans tend to separate the thought of the living animal from meat (Elias, 1939: 118-119; Goody, 1982: 135-139; Mennell, 1996: 304316). For them, the phenomenon of the disappearance of what in this article is called 'the animal origins of meat' is part of the civilising process, which continuously improves human behaviour. What this article defines as 'animal origins of meat' is every part of meat that reminds us that once the meat we eat was a living being. Thus, animal origins of meat are parts of the animal like heads, legs, tails, which may be considered evidence of the living past of the animal. The more human beings can see these parts throughout the food process, the more they are aware that a steak was once a living animal.

In addition, Goody has also created a scheme in which he visualises the four stages through which humans relate to food during their lives: Production (placed in the farm), Distribution (in the market), Preparation (in the kitchen) and Consumption (at the table) (Goody, 1982: 37).

In this article, firstly the disappearance of the animal origins of meat in Britain, France and Italy is applied to the four stages of Goody's scheme to find out whether or not, how and to what extent each stage of the scheme is affected by this disappearance. Therefore, the first research question asks to what extent each stage of Goody's scheme has witnessed a disappearance of the animal origins of meat in Britain, France and Italy. Although they present differences in their approaches to food, Britain, France and Italy have witnessed the phenomenon in similar ways, with differences linked to industrialisation that have not affected the long-term process in depth. What is more, Elias, Goody and Mennell, dealing with this issue, often refer to western Europe in general and not to singular countries, because beyond national characteristics, the whole area has undergone the process in a similar way.

Secondly, over the last few years, at least two different teams, one in the US and one in Europe, have been working on creating 'cultured meat'. In the first case, Professor Patrick Brown and his team are preparing meat without meat, a food totally grown in the laboratory. In the second case, 
Doctor Mark Post, at the University of Maastricht, is trying to obtain meat from stem cells (Hanlon, 2012). This work argues that cultured meat may have deep links to one stage of Goody's scheme, that of Production. From all of this, the second research question asks: drawing on the Goody's stage of Production, to what extent is cultured meat, generally considered a shocking novelty, a form of continuity with the past and a further step in Elias' civilising process?

Meat is today considered a problem: human disease, pathogens, medical costs, pollution and animal suffering are the most significant issues linked to meat consumption. Cultured meat, although at an experimental stage, seems to be a potential solution for all the problems meat is accused of (Edelman et al., 2005). Cultured meat, however, is also strongly criticised by naturalness advocates, while vegetarians and animal rights activists have different views on this (Welin and Van Der Veele, 2012). Beyond the diverse opinions, what is important here is that cultured meat may mark the last form of detachment of meat from its animal origins, making people forgetful that eating meat means the death of an animal.

The disappearance of the animal origins of meat has never been applied to Goody's scheme and has never been investigated throughout the whole meat system. Moreover, cultured meat has never been associated with Goody's stage of Production and has never been linked to the other forms of disappearance of the animal origins of meat related to distribution, preparation and consumption. Analysing historical data and articles on cultured meat, the research questions are answered finding out how each stage of Goody's scheme behaves towards the issue of meat, focusing more on the stage of Production, being deeply affected by the 'new issue' of cultured meat.

Before answering the research questions, in the following section Goody's scheme is developed and explained.

\section{Goody's Scheme}

After having analysed diverse food cultures around the world, in 1982 Goody published a scheme which summarises the entire food system. He argues that 'the study of the process of providing and transforming food covers four main areas' (Goody, 1982: 37):

\section{(Goody's scheme in separate file)}

After the scheme, Goody also writes that to this 'should be added a fifth phase' (Goody, 1982: 37), that of disposal, but he puts this stage also graphically outside of the scheme and in the following 
pages he just delves into the first four phases. What is more, in relation to this article, it is important to say that disposal has little to do with the animal origins of meat. Animal heads and legs, in fact, have already disappeared during the previous stages. For these reasons, this article focuses just on the four stages included in the scheme.

Explaining the different stages of his scheme, Goody describes the first two as dominated by economics and politics respectively, and the third and the fourth as linked to more personal and intimate issues, like gender and identity (Goody, 1982: 37-38). Actually, Distribution seems the most outdated, limited to the acts of allocating and storing. Analysing Goody's scheme, Marshall says that this stage 'might include reference to the nature of transaction, within and without the group, the quality of distribution, the technology of transport and storage and the periodicity of distribution' (Marshall, 1995: 11). Nowadays, thirty years after Goody's words, the process of distribution has deeply changed, involving more activities and many more people than in the past (Dunne et al., 2010: 4). For these reasons we could replace Goody's old category of allocating/storing with the newer concept of retailing, 'the final activities and steps needed to place a product in the hands of the ultimate consumer' (Dunne et al., 2010: 35). It is a long and complex process, which today has overtaken agriculture, becoming the most important stage in the western food system (Heasman and Lang, 2004: 15-16). In fact, people working in retailing and on identifying and shaping consumer's needs today have more influence than farmers, who are simply requested to adapt their produce to the consumer's needs. 'Put another way, food production is being posited as a victim of consumer choice!' (Heasman and Lang, 2004: 15). All of this has led to powerful retailers that get bigger every year. In Britain, for example, 'four large corporate giants: Tesco, Sainsbury, Asda and Morrisons ... control up to 75 percent of the grocery business' (De Vogli, 2013: 155).

Basing food research on Goody's table is not a novelty. Beardsworth and Keil (1997: 47-49) find it basic but complete, while Wood and Brotherton consider it 'stripped of temporal elements but relying on a weak correspondence theory between: processes (e.g. growing food); phases (e.g. production); and location (e.g. farm)' (Wood and Brotherton, 2008: 444). Anderson defines Goody’s scheme as 'a classic formulation' of the food system (Anderson, 2005: 238).

There are many other models of the food system. That of Beardsworth and Keil (1997: 34) is more concerned with shortages and sustainability, while that of Freckleton et al. is more based on import/export (Beardsworth and Keil, 1997: 49). In the end, the simplicity of Goody's scheme helps to better structure this research. 


\section{The Two Images That Are Being Detached From Each Other: Existing Literature}

Vialles argues that 'we have not wish to eat corpses (we are carnivores, not carrion-eaters), so animals have to be slaughtered. But we demand an ellipsis between animal and meat' (Vialles, 1994: 5). Splitting the two images is a modern need that our ancestors did not know: 'From the thirteenth century to the sixteenth, calves' eyes were considered the most exquisite delicacy of all' (ToussaintSamat, 2009: 94).

Today many people tend to set the two images apart and do not want to bridge the gap between them (Hopkins and Dacey, 2008: 580). Masson, a food researcher (but significantly also a psychoanalyst) underlines this sort of detachment and lists all the techniques that we use to separate the two images in our minds (Masson, 2009: 160-162). Among them, denial, ignoring, minimizing, and 'not in my backyard' are the most frequent. Yet, 'reversal' is also useful as 'instead of concerning ourselves with the suffering of the animals, we claim that it is we who are the ones who suffer by having to keep these animals fed and safe' (Masson, 2009: 162). Additionally, 'splitting' is popular as 'we can say that there are good farms and bad farms, and refuse to have anything to do with the latter' (Masson, 2009: 162), considering 'good farms' those in which animals are treated well, and 'bad farms' the factory farms. Related to this, splitting is also Safran Foer's (2010) strategy when he faces the meat issue. In fact, he finds two kinds of meat: ethical meat, which is obtained from animals that lived well; and non-ethical meat, obtained instead from factory farmed animals.

Moreover, Adams points out that 'behind every meal of meat is an absence: the death of the animal whose place the meat takes ... Meat becomes unanchored by its original referent (the animal), becoming instead a free-floating image, used often to reflect women's status as well as animals" (Adams, 2010: 13).

All these authors are aware of the detachment between animals and meat, but what this work argues is that this detachment involves every step of the 'story of food', each stage of Goody's scheme. In the following sections, the relationships between each stage of Goody's scheme and the animal origins of meat are analysed. In chronological sequence, the first detachment occurs from the stage of Consumption.

\section{The First Detachment: From Consumption}

Eating meat has always been considered different from eating other items of food. This particular approach started during the ancient age: 'There has always been a kind of vague ambiguity in 
human attitudes towards the consumption of meat and its "essence", fat, as if man were appropriating God's creatures, as Father de Acosta suggests, and must apologize, conciliating the deity with sacrifice' (Toussaint-Samat, 2009: 92). The appropriation of 'God's creatures' also led to the higher status of the meat eater, the so-called 'noble carnivore' described by Watts (2006: 30). The process of disappearance from the step of Eating undertaken by the animal origins of meat has deep roots in history. It is the oldest among the other steps and has not reached a conclusion yet. As noted by the philosopher Norbert Elias, it is part of the Civilizing Process. At the beginning, in fact,

In the upper class of medieval society, the dead animal or large parts of it are often brought whole to the table. Not only whole fish and whole birds (sometimes with their feathers) but also whole rabbits, lambs and quarters of veal appear on the table, not to mention the larger venison, or the pigs and oxen roasted on the spit. The animal is carved on the table (Elias, 1939: 118-119).

These habits have changed since the late Middle Ages, and Mennell finds that 'since the Renaissance Europeans generally have become less tolerant of cruelty towards animals' (Mennell, 1996: 305). Related to this, 'from the time of the Renaissance ... feeling toward meat-eating gradually underwent quite widespread changes' (Mennell, 1996: 304). It is just the beginning of a long process. 'With time, however, remainders of the animal's nature ... are removed: first the head, or feet, or tail and so on' (Fiddes, 1991: 100).

However, the process of detachment between the living animal and meat at the stage of consumption would not have been the same without religion. In many forms of worship, in fact, food in general and meat in particular symbolically inhabit myths and rituals through which believers confirm their memberships and mark boundaries between them and the non-believers (Goyan Kittler et al., 2011: 79-101). For example, on the one hand in the Eucharist 'Catholics ... recognize that Jesus himself is present with them in the bread' (Zanzig, 1997: 114). On the other hand, Christianity reduces meat consumption (Goyan Kittler et al., 2011: 86-87). Also in Islam, food is sacred, and "is never to be thrown away, wasted or treated with contempt" (Goyan Kittler et al.; 2011: 92). Islam forbids, among the others, pork and 'improperly slaughtered animals ... An animal must be killed in a manner similar to that described in the Jewish laws' (Goyan Kittler et al., 2011: 92). In fact, Jewish people eat all kinds of meat apart from pork, but the meat must be slaughtered with a precise method. The main rule is that even the smallest drop of blood must be excluded (Goyan Kittler et al., 2011: 82). Finally, Hinduism bans beef and discourages the consumption of pork and other kinds of 
meat. Prasad is the name of the Hindu food believed to be the leftovers of the deity, that becomes sacred and is given to the poor to feed their bodies and their souls (Fowler, 1997: 48).

Mennell argues that religions have changed the relationships between humans and animals, by increasing the embarrassment of eating meat (Mennell, 1996: 304-305), even when meat is intrinsically linked to worship, as the turkey in American Thanksgiving (Baker, 2010: 47). Here meat, in various ways and with precise rituals, underlines a sense of community in the home (Wallendorf and Arnould, 1991). Originally, in the Eighteenth and Nineteenth Centuries, turkey meat's links to the living animal were always vivid. Turkeys were in fact raised in anticipation for Thanksgiving day, and then slaughtered and eaten (Barth, 2000: 87). However, as reported above in relation to Goody' and Mennell's theories, at that time the process of detachment had already started and popular magazines, along with images of turkey shooting, also published 'Nast's humorous cartoons of turkey-hunted nightmares suffered by overindulgent small boys' (Baker, 2010: 90). These links have loosened over the years with the habit of buying turkey meat for Thanksgiving instead of raising the animal (Barth, 2000: 87-88).

The process of disappearance of the animal origins of meat from Consumption is slow but unstoppable. Being an ongoing process, however, even today forms of resistance occur in many European countries. In Sardinia, for example, one of the most traditional dishes sees the piglet brought whole to the table (Oliva and Poli, 2004: 14, 104). However, when Steven Raichlen gathers the many places over 'six continents' in which it is still possible to eat barbecued whole animals, among the many cases in places like Uruguay, Bali, Japan, and other countries, just one is from western Europe (barbecued lamb in Greece) (Steintrager, 2012). It simply means that western Europe displays a different sensibility towards the topic.

In western culture, in fact, eating from a whole animal (or a whole small animal), makes many people feel uncomfortable.

There are people who are uncomfortable carnivores and they know the explanation of this oddity. They do despise animal cruelty ... They know in fact that they rely on the supermarket disconnection between animal and meat in order to continue eating meat, and ... feel guilty about it all. The problem is that they love eating meat (Hopkins and Dacey, 2008: 580).

Vialles points out that, by eating meat without its animal origins, we de-animalise it. She states that 'clearly, this de-animalising of meat as food constitutes an attempt to justify it ... to edulcorate blood into sap' (Vialles, 64). This relates to 'the culinary practices that, still today, associate meat- 
eating closely with the consumption with vegetables' (Vialles, 64). In the meantime, consumers' expectations have changed, and 'supermarkets have clearly derived particular competitive advantage from presenting meat in conspicuously hygienic conditions with all preparation completed out of sight' (Fiddes, 1991: 96). But what happens at the butcher's and in the supermarket concerns another of Goody's stages, that of Distribution.

\section{The Second Detachment: From Distribution}

The disappearance of the animal origins of meat from the stage of Distribution is more recent than that from Consumption. Throughout the complex process of retailing, this work argues that the detachment is more visible in the slaughterhouse and the butcher's.

Until the 18th century, slaughtering and butchery were carried out by the same person and occurred in the city (Lee, 2008: 47). But at the beginning of the 19th century, a new view on killing animals cast a worrying shadow on this job (Vialles, 1994: 17; Otter, 2008: 105-106). Therefore, in the majority of European cities slaughterhouses became somehow 'institutions', while 'private slaughtering' was banned (Vialles, 1994: 17). 'The dissociation of slaughtering and butchery ... "cleared" the butcher and made him "innocent" ... and took account of the new sensibilities. But ... transferred the images of death and blood to abattoirs and those who worked in them' (Vialles, 1994: 17).

Besides Vialles in France, Mennell (1996: 308) acknowledges the occurrence of this process in Britain, and Braschi and Sotgia (2010: 78) in Italy. Moreover, being 'dirty' places, with time slaughterhouses were built further away from the city centres (Lee, 2008: 51), while additionally slaughterers got more and more distanced from their local communities (Claflin 2008: 40) by using specific language and codes of self-representation. Citing Maxime Du Camp, Claflin reports that 'an anatomy professor would hardly recognize' (Claflin 2008: 40) the words they used to mean the various parts of the animals. Moreover, they used to disguise 'themselves with false mustaches, beards and glasses' (Claflin 2008: 40), to clench knives, walk aggressively and wear blood-stained clothes. 'They were not simply men at work but characters on a stage' (Claflin 2008: 40). All of this was part of the new darkened trait of this activity and its related buildings.

Certainly the move of slaughterhouses from city centres to more deserted lands was not brought about just by the new view of killing animals. Mennell argues that 'often the overt motivation of legislation and regulation was concern about public health and hygiene' (Mennell, 1996: 308) and also economic reasons could be added. Old slaughterhouses in city centres have in fact been reused 
for more remunerative aims. Certainly, as in many complex social phenomena, many factors have concurred together. Among them 'feelings of repugnance also played their part' (Mennell, 1996: 308). To reinforce this point, Mennell cites many cases in which, since the 18th century, killing animals has been hidden or disguised, not to shock people's sensibility, and explains how all of this has affected cuisines (Mennell, 1996: 308-310). In Napoleon's decree of 1810 that regulated the construction of and work in slaughterhouses, among many measures to improve the health conditions, it stated that butchers 'must not have the doors of the slaughter-houses open during the killing of the animals' (Grantham, 1848: 46). Also here, along with the imaginable problems created by the smell, we can see the beginning of those 'feelings of repugnance' mentioned by Mennell.

In its move from visibility to shadow (Vialles, 1994: 5), slaughtering has followed the fate of Foucault's notion of power, visible in ancient ages, hidden in the modern era (Foucault, 1977: 187). Interestingly, today's images of slaughterhouses are a topic of counter-information documentaries, which show images that two hundred years ago were part of the urban scenario. What is more, today old slaughterhouses are often renovated and their usage transformed. In Rome, since the 1980s the old slaughterhouse has housed social and cultural organisations like the department of Architecture of the University of Rome, the MACRO museum, an organic food market and the gay village, ironically named muccassassina, a word that in Italian means (not by chance) killer cow (Braschi and Sotgia, 2010: 78-79). In an humorous way of not forgetting and of mixing the past function of the building and the prejudices against gays, the organisers chose this name imagining a revolution in which the killed (the cow but also the homosexual dignity) could turn into an unarmed killer (Muccassassina, 2013).

Hidden in the slaughterhouses, however, animal origins of meat were still visible at the butcher's. Large parts of the animals, in fact, were usually hung outside of the shop, often with the legs and heads, reminding customers of the link between meat and the animal. During the 20th century something new happened and politics also helped to change habits, with the introduction of new laws (Waltham Forest, 1985: 8).

In the mid 20th century, consumers still wanted to see the dead animal, touch the flesh and be aware of its origins (Waltham Forest, 1985). As can be seen in old photos (http://www.woodleynet.co.uk/old_gallery_3.htm), carcasses were part of the 'urban scenario' and people in Britain in the 1930s could park their cars close to them (http:/www.fwi.co.uk/blogs/rurallife/2011/11/). The habit of not showing whole animals has accelerated since 'independent high street butcher's shops have declined considerably' (Fiddes, 1991: 96) to make room for supermarkets. Also following consumer's requirements linked to modern life and shortage of time, 
since the second part of the 20th century, supermarkets in the whole Europe have provided meat already cut and without any animal identity (Hopkins and Dacey, 2008: 580).

The phenomenon has deep roots and stems from a new way of looking at animals, no more exploited in factories but loved as pets at home (Mennell, 1996: 306). All of this has also affected the animal's representation. Grauerholz (2007) finds that on the one hand, food industry represents meat without any animal origin, but on the other hand, animals undergo a process of 'cutification', appearing cuter than in reality. This double technique allows industry to separate the two entities of the meat and the animal.

Therefore, the separation between meat and animal has been both aesthetic and economic (Fiddes, 1991: 96). Being an ongoing process, many forms of resistance may be found. In many local markets (e.g. Arles in France), small animals like chickens and rabbits are sold with heads and legs, while in popular feasts like in Duronia in Italy, pig killing is an opportunity to celebrate (http://www.laterra.org/Immagini/maialeF1.jpg).

\section{The Third Detachment: From Preparation}

When meat arrives at the stage of Preparation, often its animal origins have been eliminated during the stage of Distribution. Before of the advent of the supermarket, however, preparation hid the parts of the animals which remind us of its natural origins. Civitello states that first animals were probably cooked with their heads, legs and tails, cooked meat being the result of accidental fires (Civitello, 2011: 3). Later, following consumption and distribution, meat underwent a process of refinement. In France, for example, 'distinct cuts and joints did not appear before the 18th century (Gascar 1973, p. 46)' (Vialles, 1994: 70).

The general public, however, had good knowledge of the different parts of the animal, as shown by memories of British people from the first half of the 20th century (Waltham Forest, 1985: 27, 31). It means that once 'purchasing meat at the butcher stall required knowledge of the product as well as confidence in one's butcher' (Watts, 2006: 37). Today, meat is 'largely cut in such a way that we cannot even tell by looking which part of the animal the tissue comes from' (Hopkins and Dacey, 2008: 580).

The stage of Preparation, however, while rejecting the whole animal, at the same time saved something else. Offal (e.g. animal's brain, lung and liver) has survived both stages of Distribution and Preparation and it actually constitutes a form of both resistance and compromise. Resistance because when we prepare it we are totally aware that we are eating an animal, and compromise 
because its shape does not resemble parts of the animal we are used to seeing, as the heads, tails and legs do. In short, offal reminds us that we are cooking and eating an animal without it resembling an animal.

People started cooking offal very early in history, because offal was cheaper (Mennell, 1996: 315; Toussaint-Samat 2009: 93). Later on, other reasons added to or replaced those linked to offal's cheapness: 'In England and France ... once the various sorts of carcass meat and offal have been shaken into some rough order of prestige value ... the virtuosos of taste can ... refine and rationalise the distinctions between what is delicate and what is repugnant' (Mennell, 1996: 315). Chefs have clearly played an important role in this revalorization of offal. Besides this, chefs also play a key-role in dealing with the animal origins of meat throughout the entire stage of Preparation. It is interesting to analyse how celebrity chefs deal with this issue on TV.

On the one hand, they hide meat (and fish) in tarts, cakes and pastiches, helping the process of disappearance that is the focus of this work. Also 'macho celebrity chefs' like Anthony Bourdain and Thomas Keller have been reported as having big problems in coping with living animals destined to become meat thanks to their culinary arts (Hopkins and Dacey, 2008: 580). The Italian chef Gianfranco Vissani, moreover, when cooking a pigeon in front of the camera, manages to hide its head not to scandalise his audience (Vissani, 2012). But animal origins of meat in cooking shows trigger repugnance at the other end of the television process too, as the audience do not want to see the animal before it becomes meat, so as not to feel guilty (Hopkins and Dacey, 2008: 579-580).

On the other hand, however, celebrity chefs use the animal origins of meat to provoke their audience. This is the case with Heston Blumenthal, who serves small and roasted dormice to people in a restaurant and just after the dinner tells them what they have actually eaten, causing expressions of repugnance and vomiting (Blumenthal, 2009). In the same series, however, Blumenthal also served dormice to celebrities that were his guests for a sophisticated dinner, but this time he served 'dormice lollipops' which looked like whole dormice (and in fact many celebrities were upset about eating them); actually they were chocolate lollipops shaped like dormice, with minced dormice meat inside. In other words, the celebrities had better treatment than the general public. Watt's 'noble carnivore' eats meat but not whole animals.

After demonstrating the disappearance of the animal origins of meat from Preparation, in the next section this article analyses how they are disappearing also from the stage of Production.

\section{The Fourth Detachment: From Production}


The animal origins of meat are disappearing from the steps of Consumption, Preparation and Distribution because of cultural and social changes. However, it is more difficult to imagine a detachment from the stage of Production, where nature appears to be irreplaceable. How do you cancel the animal to produce meat? Since we have discovered that animals are edible, human beings have always eaten them, firstly through hunting and secondly through farming (Civitello, 2011: 6). Ten thousand years after the shift from hunting to farming, we are witnessing the shift from farming animals to culturing meat. In February 2012, in fact, professor Post, of the University of Maastricht, announced the first test-tube hamburger, which could be the end of animal farming (The Economist, 2012). In June 2012, it was reported that, besides Post's announcement, also Professor Brown, from Stanford University 'for two years ... has been working on creating synthesised meat and dairy products' (Hanlon, 2012), relying therefore not on stem cells but on wholly synthetic products.

In Professor Post's project 'at present the fibres are a pallid yellowish-pink colour, rather than the red of raw ground beef, because they do not contain blood, but Prof Post plans to improve their appearance (Clookson, 2012).

Studies on culturing meat are even older than this though. Van Eelen started to study them in the 1940s, when he was a student, and only in 1999 did he achieve funds and academic credit (Specter, 2011: 32). Experiments went on and

in 2001, NASA funded an experiment, led by Morris Benjaminson, that focused on producing fresh meat for space flights ... Then, in 2004, after continued lobbying from van Eelen, the Dutch government awarded two million euros to a consortium of universities ... it has helped turn the Netherlands into the in-vitro-meat world's version of Silicon Valley (Specter, 2011: 32).

These attempts have tried to detach the animal origins of meat from meat production. Post's and Brown's experiments seem to be at an advanced stage, with Post foreseeing that in 10 or 20 years they will 'mass produce' (Clookson, 2012) the new meat and that 'in 50-60 years it may be forbidden to grow meat from livestock' (Hanlon, 2012). If and when this happens, producing meat will mean cancelling the whole animal from production and never seeing an animal with a head, tail or legs throughout the entire meat process. Actually, in Post's project, 'the most efficient way of taking the process forward would still involve slaughter' (Collins, 2012). Brown's project, instead, does not entail killing animals at all.

It seems that we are approaching what Winston Churchill predicted in 1932, 'fifty years hence, we shall escape the absurdity of growing a whole chicken in order to eat the breast or wing, by growing 
these parts separately under a suitable medium' (Hanlon, 2012). Beyond the absurdity found by Churchill, eating meat is today considered 'dirty', with the scientific and technological implications of factory farming underlined by Fairlie (2010) and Hyslop (2012). Farming is today accused of producing 'two-thirds of human-related nitrous oxide ... [which] is estimated to have 296 times the global warming potential of CO2' (Mulvaney, 2010: 147). Moreover, animals 'raised in factory farms produce methane from digestion and feces ... [This] is the single-largest source of methane emissions in the United States, and a methane molecule is 23 times as effective at retaining heat as one molecule of carbon dioxide' (Johansen, 2009: 258).

In this gloomy outlook, cultured meat is today seen by many as a sort of earth's saviour since it may reduce GHG emissions by $78-96 \%$, land use by $99 \%$, and water use by $82-96 \%$ (Tuomisto, 2011 : 6117). Moreover, cultured meat

could eliminate much of animal suffering ... It could produce much healthier forms of food for humans and other animals to consume. In addition, it would allow humans the pleasure of eating meat — something we have evolved to enjoy even if we can live without it. Not surprisingly then, cultured meat has found quite a number of supporters, including well-known animal welfare activists and animal rights activists (Hopkins and Dacey, 2008: 585).

Yet, religious issues on eating animals may be overcome thanks to cultured meat (Fayaz Bhat and Fayaz, 2011: 129), at least that obtained synthetically and not through the use of stem cells. Overall, however, for the first time in human history, humans can separate the concepts of producing meat from that of living animals. Even Production, the last of Goody's categories, still attached to the living animal, could start a process of detachment. Meat production would not be linked to the animal any more.

Synthetic and cultured meat in the different forms that may be produced, however, are far from being accepted in our society without any issues. Among the critiques on them, which include the danger of biotechnologies, repugnance and 'yuk factor', moral issues, future of the potentially useless livestock (Hopkins and Dacey, 2008), one of the most interesting is the concern for naturalness, the fact that eating cultured meat is a practice which positions human beings as out of nature (Welin and Van Der Veele, 2012).

It is quite impossible to predict how humans will approach this issue in the future. We already eat GM foods and we may also get used to cultured meat, even though, at present, people perceive it as 
a sci-fi dystopia (see William Gibson's Neuromancer, or Margaret Atwood's Oryx and Crake), rather than a potential reality for the next generations.

If scientists have widely predicted what cultured meat may trigger from an environmental and technological point of view, cultural and social implications of such a discovery are still unpredictable.

How we grow, prepare, and eat our food is a deeply emotional issue, and lab-grown meat raises powerful questions about what most people see as the boundaries of nature and the basic definitions of life. Can something be called chicken or pork if it was born in a flask and produced in a vat? Questions like that have rarely been asked and have never been answered (Specter, 2011).

What is clear, however, is that cultured meat is the last (at present) link in a long chain, started during the Renaissance by bringing to the table just parts of the whole animal, and continued by moving slaughterhouses far from the city centres and stopping the display of whole animals outside of the butcher's.

\section{Conclusion}

This article has focused on how the animal origins of meat have been disappearing from three of Goody's stages, undergoing three slow ongoing processes (disappearance from Consumption, Distribution and Preparation).

Moreover, this work has also demonstrated that the phenomenon of cultured meat may be read as a further detachment of the animal origins of meat from the food system, specifically from the stage of Production. Cultured meat is therefore a stage of the 'civilising process' theorised by Elias and developed by Goody and Mennell, and what is important are all of the effects that this evolution may have in the future. There are many meat issues related to the environment, health and religion. Scientists claim that 'the average Chinese still only eats half the meat that his American counterpart does' (Moore, 2012) and warn that the planet could not survive the day when the Chinese eat the same quantity of meat as western people. Besides this and other environmental issues, such as waste of water, gases production and fields exploitation, also meat-related diseases (mad cow, avian flu) threaten meat consumption. Finally, there are religious and ethical reasons that blame meat consumption, coming from popular religions and vegetarian groups. 
The idea that all of this could be solved by just one product, that is cultured meat, makes this new food of big importance in today's debate. In conclusion, cultured meat appears to be the new answer that the human being has found to solve issues that cannot be sorted out with the current tools. The only obstacle to this last step of the process seems to be a matter of acceptability (Hopkins and Dacey, 2008). To what extent will people consider cultured meat as a food? This article has hinted at issues such as naturalness (Welin and Van Der Veele, 2012) or at the possible comparison to GM foods. This could be the starting point of the next research on this topic, to investigate if, when and how humans will experience the completion of the process and the full detachment between the image of meat and that of the living animal.

Word count: 5,879

\section{BIBLIOGRAPHY}

Adams, C. (2010) The Sexual Politics Of Meat (20 ${ }^{\text {th }}$ Anniversary Edition): A Feminist-Vegetarian Critical Theory, Continuum International Publishing, London.

Anderson, E. N. (2005) Everyone Eats: Understanding Food And Culture, NYU Press, New York (NY).

Atwood, M. (2003) Oryx And Crake, McClelland and Stewart, Toronto.

Baker, J. W. (2010) Thanksgiving: The Biography of an American Holiday, UPNE, Lebanon (NH).

Barth, E. (2000) Turkeys, Pilgrims and Indian Corn: The Story of Thanksgiving Symbols, Houghton Mifflin Harcourt, Boston (MA).

Beardsworth, A. and Keil, T. (1997) Sociology on the Menu: An Invitation to the Study of Food and Society, Routledge, London.

Blumenthal, H. (2009) Heston's Christmas Feast (TV programme), Channel 4, London. 
Braschi, S. and Sotgia, A. (2009) "Vecchi padiglioni per la nuova città: L'ex mattatoio di Roma", in Scandurra E. et al. Lungo il Tevere: Episodi di Mutazione Urbana, Franco Angeli, Roma, pp. 77104.

Civitello, L. (2011) Cuisine and Culture: A History of Food and People, Wiley publishing, Hoboken (NJ).

Claflin, K. (2008) "La Villette: City of Blood (1867 - 1914)", in Young Lee, P. (ed) Meat, Modernity and the Rise of The Slaughterhouse, UPNE, Lebanon (NH), pp. 27-45.

Clookson, C. (2012) "Scientists Prepare Test-Tube Burger", in Financial Times website. 19 February, available at:

http://www.ft.com/cms/s/0/80ed190a-5aef-11e1-a2b3-00144feabdc0.html\#axzz215imq6Zu (accessed 29 November 2012).

Collins, N. (2012) “Test Tube Hamburgers To Be Served This Year”, The Daily Telegraph website, 19 February, available at: http://www.telegraph.co.uk/science/science-news/9091628/Test-tubehamburgers-to-be-served-this-year.html (accessed 29 November 2012).

De Vogli, R. (2013) Progress or Collapse: The Crises of Market Greed, Routledge, 2013.

Dunne, P., Lusch, R. F., Carver, J. R. (2010) Retailing, Cengage Learning, Independence (KY).

Edelman P. D., McFarland, D.C., Mironov V.A., Mathenyet J.G. (2005) "Commentary: In VitroCultured Meat Production", Tissue Engineering, Vol. 11, No. 5-6, pp. 659-662.

Elias, N. (1978) The Civilising Process, vol. 1: The History Of Manners, Basil Blackwell, Oxford, first ed. 1939.

Fairlie, S. (2010) Meat: A Benign Extravagance, Permanent publications, East Meon (Hampshire).

Fayaz Bhat, Z. and Fayaz, H. (2011) "Prospectus Of Cultured Meat - Advancing Meat Alternatives", Journal of Food Science and Technology, Vol. 48, No. 2, pp. 125-140. 
Fiddes, N. (1991) Meat: A Natural Symbol, Routledge, London.

Foucault, M. (1977) Discipline and Punish: The Birth of the Prison, Penguin Books, Harmondsworth.

Fowler, J. D. (1997) Hinduism: Beliefs and Practices, Sussex Academic Press, Eastbourne.

Fullbrook, M. (2007) 'Introduction: The Character and Limits of The Civilising Process', in Fullbrook, M. (ed.) Uncivilising Process? Excess And Transgression In German Culture And Societies: Perspectives Debating With Norbert Elias, Rodopi, Amsterdam.

Gibson, W. (1986) Neuromancer, Ace-Penguin US, New York (NY).

Goody, Jack (1982) Cooking, Cuisine and Class: A Study in Comparative Sociology, Pantheon books, New York (NY).

Goyan Kittler, P. and Sucher, K. (2011) Food and Culture, Cengage Learning, Independence (KY).

Grantham, R. B. (1848) A Treatise on Public Slaughter-houses Considered in Connection with the Sanitary Question, J. Weale Architectural Library, London.

Grauerholz, L. (2007) "Cute Enough to Eat: The Transformation of Animals into Meat for Human Consumption in Commercialized Images", Humanity and Society, Vol. 31, No. 4, pp. 334-354.

Hanlon, M (2012) “Fake Meat: Is Science Fiction On The Verge Of Becoming Fact?”, The Guardian website, 22 June, available at: http://www.guardian.co.uk/science/2012/jun/22/fake-meatscientific-breakthroughs-research?INTCMP=SRCH (accessed 29 November 2012).

Heasman, M. and Lang, T. (2004) Food Wars: The Global Battle for Mouths, Minds and Markets, Earthscan, London.

Hopkins, P. and Dacey, A. (2008) "Vegetarian Meat: Could Technology Save Animals And Satisfy Meat Eaters?” Journal Of Agricultural And Environmental Ethics, Vol. 21, No. 6, pp. 579-596. 
Hyslop, G. (2012) “Stem Cells Could Revolutionise The Food Industry”, South African Food Review, Vol. 39, No. 3, pp. 16-16.

Johansen, B. E. (1997) The Encyclopedia of Global Warming Science and Technology, Volume 1, ABC-CLIO, Santa Barbara (CA).

Lee, P. Y. (2008) "Siting the Slaughterhouse: From Shed to Factory", in Young Lee, P. (ed) Meat, Modernity and the Rise of The Slaughterhouse, UPNE, Lebanon (NH), Pp 46-69.

Marshall, D. (1995) Food Choice and the Consumer, Springer, New York (NY).

Masson, J. (2009) The Face on Your Plate: The Truth About Food, Norton \& Co, New York.

Mennell, S. (1996) All Manners of Food: Eating and Taste in England and France from the Middle Ages to the Present, (first edition 1985), University of Illinois Press, Champaign (IL).

Moore, M. (2012) "China Now Eats Twice As Much As the United States", The Telegraph website, 12 October. Available at:

http://www.telegraph.co.uk/news/worldnews/asia/china/9605048/China-now-eats-twice-as-muchmeat-as-the-United-States.html.

Muccassassina (2013) Mucca Story, available at: http://www.muccassassina.com/wp/mucca-story/ (accessed 26 March 2013).

Mulvaney, D. (2010) Green Food: An A-To-Z Guide, Sage, London.

Oliva, P. and Poli, M. G. (2004) Cucina Sarda, Giunti publishing, Milan (Italy).

Otter, Chris (2008) "Civilising Slaughter: The Development of The British Public Abattoir 18501910”, in Young Lee, P. (ed.) Meat, Modernity and the Rise of The Slaughterhouse, UPNE, Lebanon (NH), pp. 89-106.

Safran Foer, J. (2010) Eating Animals, Penguin, London. 
Specter, M. (2011) "Test-Tube Burgers: How long will it be before you can eat meat that was made in a lab?". The New Yorker, 23 May, vol. 87, No. 14, p. 32

Steintrager, M. O. (2012) "Whole-Animal Barbecue Around The World. In Gourmet Live", Gourmet website, 18 July, available at:

http://www.gourmet.com/food/gourmetlive/2012/071812/raichlen-barbecue (accessed 29 November 2012).

The Economist (2012) “Hamburger Junction”, 25 February.

Thomas, K. (1983) Man And The Natural World: Changing Attitudes in England, 1500-1800, Allen Lane, London.

Toussaint-Samat, M. (2009) A History of Food, Wiley publishing, Hoboken (NJ).

Tuomisto, H. and Joost Teixeira de Mattos, M. (2011) "Environmental Impacts Of Cultured Meat Production", Environmental Science \& Technology, Vol. 45, No. 14, pp. 6117-6123.

University of Sussex, Institute of Development Studies (2001) IDS Bulletin, vol. 32, IDS Sussex, Brighton.

Vialles, N. (1994) Animal to Edible, Cambridge University Press, Cambridge.

Vissani, G. (2012) Ti Ci Porto Io (TV programme), La7, Rome (Italy).

Wallendorf, M. and Arnould, E. (1991) "We Gather Together: Consumption Rituals of Thanksgiving Day”, Journal of Consumer Research, Vol. 18, No. 1, pp. 13-31.

Waltham Forest Oral History Workshop (1985) Waltham Forest Memories 2: Pigs Head \& Pease Pudding, Waltham Forest, London.

Warde, A. (1997) Consumption, Food and Taste, Sage, London. 
Watts, S. (2006) Meat Matters: Butchers, Politics, and Market Culture in Eighteenth-century Paris, University of Rochester press, Rochester (NY).

Welin, S. and Van Der Veele, C. (2012) “Cultured Meat: Will It Separate Us From Nature?” In Potthast, T. and Meisch, S. (ed.) Climate Change And Sustainable Development, Wageningen Academic, The Netherlands, pp. 348-351.

Wood, R. C. and Brotherton, B. (2008) The Sage Handbook Of Hospitality Management, Sage, London.

Zanzig, T. (1997) Understanding Catholic Christianity, Saint Mary Press, Winona (MN). 